\title{
ПРИМЕНЕНИЕ СТЭКИНГА С БОЛЬШИМ ОБЪЕМОМ ОБРАЗЦА В КАПИЛЛЯРНОМ ЗОННОМ ЭЛЕКТРОФОРЕЗЕ ДЛЯ ОПРЕДЕЛЕНИЯ ВЕЩЕСТВ- МАРКЕРОВ КАЧЕСТВА КОФЕ И ЧАЯ
}

Тищенко Е.А., Цюпко Т.Г., Гущаева К.С., Коробко М.М. ФГБОУ ВО «Кубанский государственный университет», Краснодар, Россия ekaterina-pydyk@mail.ru

DOI: 10.26902/ASFE-11_196

Для оценки качества пищевого продукта весьма полезными являются сведения о его компонентном составе. Ценную информацию можно получить не только по уровню содержаний мажорных биологически активных соединений в продукте, например, кофеина в чае и кофе, но и минорных компонентов, которые могут характеризовать технологические особенности производства продукта. Определение последних в сложных пищевых матрицах сепарационными методами часто связанно с длительной и трудоемкой пробоподготовкой, необходимой для очистки пробы и/или предварительного of-line концентрирования аналита, позволяющего достичь приемлемого для его детектирования концентрационного уровня. Один из подходов повышения чувствительности определения микрокомпонентов методом капиллярного электрофореза с УФ-видимым детектированием (КЗЭ-УФ) заключается в создании условий для on-line концентрирования за счет введения большого количества образца и увеличения количества аналита в зоне до обнаружения. Такой подход, называемый стэкинг с большим объемом образца и обращением полярности (LVSS), успешно применен в капиллярном электрофорезе для определения различных микрокомпонентов в биологических жидкостях, природных объектах и некоторых пищевых продуктах и позволяет сконцентрировать аналиты с кратностью до $10^{3}$ раз.

Целью нашей работы являлась оценка возможности применения стэкинга с большим объемом образца и обращением полярности в методе капиллярного зонного электрофореза (КЗЭ) для определения минорных веществ-маркеров качества пищевого продукта на примере никотиновой кислоты (НК) в растворимом кофе и теофиллина (ТФ) в черном чае.

Определение аналитов в продуктах проводили с использованием системы Agilent ${ }^{3 \mathrm{D}} \mathrm{CE}$ G1600A, оснащенной немодифицированным кварцевым капилляром. Пробы кофе и чая представляли собой разбавленные в 10n раз водные экстракты образцов продукта. Подобраны оптимальные условия разделения и on-line концентрирования аналитов, включающие время ввода образца, концентрацию и значение $\mathrm{pH}$ фонового электролита, рабочее напряжение, время и напряжение обращения полярности для удаления матрицы из капилляра. Детектирование НК и ТФ проводили при длинах волн 254 и 272 нм соответственно. Время анализа в обоих случаях не превышало 25 мин.

В работе показано, что с применением процедуры LVSS удалось сконцентрировать НК в 70 раз, что позволило проводить ее определение в растворимом кофе в диапазоне 250-2500 мкг/Г с относительной погрешностью 14 \%. В режиме КЗЭ-УФ с применением боратного буферного раствора в качестве фонового электролита в диапазонах концентраций 50-110 Мм, значений $\mathrm{pH} 8.0-10.0$ и напряжения в системе 10-30 кВ не удалось обнаружить ТФ в экстракте черного чая. Предварительно проведенная процедура on-line концентрирования аналита позволила обнаружить ТФ в пробе. На модельных растворах показана возможность концентрирования ТФ в 20-30 раз, что достаточно для определения аналита в реальных образцах. Показана также возможность одновременного определения ТФ и теобромина в черном чае. Таким образом, LVSS-КЗЭ-УФ является эффективным методом определения веществ-маркеров качества пищевых продуктов на примере НК в растворимом кофе и ТФ в черном чае.

Работа выполнена при финансовой поддержке РФФИ, грант r_a 1943230010. 